\title{
DiE ASSIMILASIE VAN LIDMATE IN DIE PLAASLIKE GELOOFSGEMEENSKAP
}

Author:

Enrich F. Basson ${ }^{1}$

\section{Affiliation:}

${ }^{1}$ Department of Practical

Theology, University of

South Africa, South Africa

Correspondence to:

Enrich Basson

email:

enrich@citc.co.za

\section{Postal address:}

PO Box 4268

Rietvalleirand 0174,

South Africa

\section{Keywords:}

membership; assimilation; growth; integration; participation; culture; values

\section{Dates:}

Received: 19 Nov. 2009

Accepted: 06 Apr. 2010

Published: 13 Sept. 2010

How to cite this article: Basson, E.F., 'Die assimilasie van lidmate in die plaaslike geloofsgemeenskap', HTS Teologiese Studies/ Theological Studies 66(2), Art. \#827, 6 pages. DOI: 10.4102/hts.v66i2.827

\section{This article is available} at:

http://www.hts.org.za

(C) 2010. The Authors. Licensee: OpenJournals Publishing. This work is licensed under the Creative Commons Attribution License.

\section{ABSTRACT}

The assimilation of church members into the local faith community In this article, the assimilation of members into the faith community is discussed. When a church has found its identity in being a 'missional faith community', the outcome is growth. Growth cannot take place if the church is unable to assimilate new members into church life. People are only assimilated into the faith community when they are interconnected through relationships, and experience a fundamental sense of belonging. This article discusses aspects of membership assimilation, namely intention, active participation, and culture. A model is proposed whereby leaders can evaluate the functional worth of people for the faith community at any level of assimilation. This model can also assist leaders in creating processes to assimilate members more effectively.

\section{INLEIDING}

Hierdie artikel handel oor die problematiek van die assimilasie (oftewel opneming) van nuwe lidmate in die plaaslike geloofsgemeenskap. Assimilasie verwys na die geloofsgemeenskap se vermoë om nuwe lidmate by die gemeenskap te integreer, en hulle in liefdevolle verhoudings aan mekaar te verbind. Dit dui dus op 'n verskeidenheid formele en informele prosesse wat mense in staat stel om deel te word van die geloofsgemeenskap (Dudley 1998:114). Wanneer 'n geloofsgemeenskap ' $n$ missionale identiteit ontdek, is groei die uitkoms (Basson 2006:37). Groei kan egter nie doeltreffend plaasvind as daar nie ' $n$ effektiewe assimilasieproses in die geloofsgemeenskap bestaan nie (Ford 2007:49). Hierdie artikel wys op verskillende noodsaaklike aspekte ten opsigte van die assimilasie van nuwe lidmate, en stel ' $n$ model voor wat die grondslag vir toekomstige assimilasieprosesse in geloofsgemeenskappe kan uitmaak.

\section{AGTERGROND EN PROBLEEM}

In Pinkstergemeentes is daar ' $\mathrm{n}$ sterk klem op lidmaatskapgroei. Hiervoor word programme soos kerkgroeiprojekte, Natural Church Development (NCD), Evangelism Explosion (EEIII) en Kingdom Advancement Ministries (KAM) onder meer gebruik. Gemeentegroei vind onder andere deur evangelisasieprojekte plaas, maar meestal vanweë lidmaatoordrag van ander Christelike gemeentes (Frost \& Hirsch 2003:213). Die probleem van gebrekkige assimilasie ontstaan juis met dié uitbreiding van die kerk se lidmaattal. Die opneming en assimilasie van nuwe lidmate in Pinkstergemeentes vind meestal op ' $n$ baie eenvoudige grondslag plaas. Die kerk bied ' $n$ lidmaatontmoetingsgeleentheid aan, waartydens die aansoeker aan die geloofsgemeenskap bekend gestel en aangemoedig word om betrokke te raak (Dever \& Alexander 2005:61). Die enigste aspek wat hierdeur beoordeel word, is die intensie van die voornemende lidmaat. Hierna word lidmate gewoonlik opgeneem sonder om hulle behoorlik by die geloofsgemeenskap te integreer. Dit kan tot konflik en uiteindelike lidmaatverlies lei, onder andere omdat die waardestelsel van die nuwe lidmate van die geloofsgemeenskap s'n kan verskil of selfs daarmee bots (Dobson, Leas \& Shelley 1992:116).

Die assimilasieproses (vgl Ef 4:1-6; 1 Kor 1:10-17, 10:16; Fil 1:27-28, 2:1-5) was skynbaar reeds in die vroegste Christelike gemeentes (55-60 nC) 'n uitdaging (Bruce 1977:173; Hinson 1996:77). Die grondslag vir die assimilasie van nuwe lidmate in die Nuwe-Testamentiese tyd was van meet af aan 'eenheid' in geloof (vgl 1 Kor 1:10). Dié eenheid impliseer om verenig te wees in gesindheid en mening. Om verenig te wees strek verder as om saam te aanbid. Dit beteken ook om ten volle aanvaar te word en deel uit te maak van die totale lewe in die plaaslike geloofsgemeenskap. Hierdeur kan die geloofsgemeenskap wat die heil van Christus deelagtig geraak het, verenig optree soos wat dit ' $n$ nuwe gemeenskap betaam (Smit 2003:163). In die Pauliniese briewe kom die gedagte van assimilasie sterk na vore (Meeks 2003:87-88). Nuwe lidmate in die geloofsgemeenskap word nou mekaar se broers en susters (vgl Gal 4:19; 1 Kor 4:14; 2 Kor 6:13,12:14). Eenheid, as kenmerk van die kerk in die konteks van die plaaslike geloofsgemeenskap (Guder 1998:255), stel die kerk in staat om inklusief te wees, sodat gelowiges ongeag kerkagtergrond, ras, nasionaliteit, taal, kultuur, stand, geslag of afstand, voel dat hulle behoort (Möller 1994:308-311). Sodanige eenheid weerspieël volgens Christus geloofwaardigheid ten opsigte van die 'gestuurde' aard, of die missionaliteit, van die kerk (vgl Joh 17:20-21). Slegs wanneer die plaaslike geloofsgemeenskap in staat is om mense ten volle op te neem kan hulle waarlik inhoud aan die eienskap van 'eenheid' gee (Hinson 1996:77).

Op grond van Handelinge 2:47 waar God 'mense by die gemeente [gevoeg]' het, kan 'n meganiese assimilasieproses krities beoordeel word. Christian Schwarz (1996:8-9) ondersteun hierdie beginsel ten volle in sy teorie oor die biotiese potensiaal van geloofsgemeenskappe. Volgens hom vind groei vanself plaas wanneer die weerstandsfaktore beperk word sodat die omgewing groei aanmoedig. Hy praat van 'selforganisasie' (Schwarz 1996:10), en gebruik die begrip 'vanself', wat Jesus ook in Markus 4:26-29 gebruik, om die geloofsgemeenskap se biotiese potensiaal aan te dui. Schwarz (1996:14) beskou menslike intervensie as ' $n$ tegnokratiese paradigma wat hoofsaaklik deur die 
Kerkgroeibeweging ingespan is, en wat die rol van metodes en prosesse oorskat. Hy het dalk gelyk in die opsig dat dit God is wat groei veroorsaak, maar weerspreek sy eie teorie in ander opsigte. Schwarz (1996:28) noem funksionele strukture as een van die karaktereienskappe wat uiteindelik nie 'vanself' tot stand kan kom nie, maar menslike intervensie veronderstel. Dit verbreek dus die 'vanself'-beginsel. Uiteindelik is die plaaslike geloofsgemeenskap in wese nie net 'n lewende organisme nie, maar ook 'n sosiale werklikheid met organisatoriese kenmerke. Die twee pole 'organisme' en 'organisasie' behoort nie teen mekaar afgespeel te word nie, maar staan in 'n bipolêre spanningsverhouding teenoor mekaar. Die groei in die kerk hang dus nie net van God se werk af nie, maar verg deelname van mense as medewerkers van Christus (vgl 1 Kor 3:6-10). Dit is dus duidelik dat, terwyl God die biotiese potensiaal skep, dit nie die plaaslike geloofsgemeenskap van die verantwoordelikheid onthef om saam te werk nie. Terwyl God verantwoordelik is vir die ontstaan van die geloofsgemeenskap, en die toevoeging van dié wat gered word, is dit die plaaslike geloofsgemeenskap se verantwoordelikheid om die lidmaatskapgroei in prosesse soos assimilasie te organiseer.

Meeks (2003:74) som die gevolg van volledige assimilasie soos volg op: 'these groups enjoyed an unusual degree of intimacy, high levels of interaction among members, and a very strong sense of internal cohesion'. ' $\mathrm{n}$ Sterk band tussen lidmate is een van die prominente kernfunksies van 'n geloofsgemeenskap (Van der Ven 1993:82). Dit verwys hoofsaaklik na die koinoniaverband, wat net moontlik is vanweë integrasie en onderlinge verbintenisse. Die toets van ware assimilasie is of lidmate uiteindelik ervaar dat hulle tot die geloofsgemeenskap behoort. Murray (2001:156) meen dat mense nie geloofsgemeenskappe verlaat omdat hulle nie meer glo nie, maar omdat hulle nie meer voel hulle behoort nie. Ford (2007:49) het weer in sy navorsing bevind dat gemeentes in hul assimilasieproses oormatig op onpersoonlike kommunikasie, soos inligtingsbrosjures, lidmaatskapklasse en so meer, konsentreer, terwyl assimilasie 'n persoonlike, verhoudingsgegronde proses behoort te wees. Die uitkoms van 'n behoorlike assimilasieproses is waarskynlik 'n sterk verbintenis tussen lidmaat en gemeente. Bosch (1979:200) beskryf ' $n$ missionale geloofsgemeenskap as ' $n$ gemeente wat in staat is om buitestanders gemaklik op te neem. Dit beskou missionaliteit dus nie net as deelname aan die Missio Dei nie, maar ook as die ontwikkel van strukture en prosesse wat mense behoorlik in die geloofsgemeenskap opneem.

Plaaslike gemeentes konsentreer veral op die Sondagerediens. Bywoning van eredienste moet egter nie met lidmaatassimilasie verwar word nie. Terwyl die erediens die hoogtepunt van die geloofsgemeenskap se werksaamhede is, dui die blote bywoning daarvan op 'n Sondag nog geensins op 'n verbintenis nie (Basson 2006:138). Dit is slegs wanneer mense die grondliggende ervaring het dat hulle tot die geloofsgemeenskap behoort en ten volle daarvan deel uitmaak, dat assimilasie suksesvol plaasgevind het.

Assimilasie is 'n dinamiese proses waardeur nuwe lidmate by die wese van die plaaslike geloofsgemeenskap geïntegreer word. In hierdie verband ontstaan die vraag watter aspekte belangrik is vir die assimilasieproses van nuwe lidmate, en of 'n sinvolle model ontwikkel kan word om die assimilasieprosesse in geloofsgemeenskappe te bevorder en te vergemaklik.

\section{ASSIMILASIE}

Assimilasie kan beskou word as 'n proses waardeur persone betrokke gemaak en ingelyf word by die kultuur sodat hulle volledig by die lewe van die geloofsgemeenskap geïntegreer kan word, om sodoende in die identiteit van die gemeente opgeneem te word. In die vroegste Christelike gemeentes was die fokus van die assimilasieproses op die verskillende rituele. In die Pauliniese briewe (vgl Gal 3:27-28; 1 Kor 12:13) val die klem byvoorbeeld sterk op die doop as die inwydingsritueel van die gelowige in die geloofsgemeenskap (Meeks 2003:150). Die Nagmaal word ook gereeld as die ritueel van solidariteit in die geloofsgemeenskap gevier (Meeks 2003:157). Ander institusionele aspekte soos 'kategese', dissipline, skriftuur en die apostoliese bediening was van die sake wat in die proses van assimilasie gebruik is. ' $\mathrm{n}$ Verwysing na 'kategese' kom in Galasiërs 6:6 (ho katechoumenos/t ' $n$ katechounti) voor, en verwys na die vroeë voorkoms van 'n eenvoudige assimilasieproses wat na die eerste eeu meer omvattend begin raak het (Ferguson, Mchuah \& Norris 1997:223). Assimilasie het uit twee fases bestaan, naamlik die van 'belangstellendes' (audientes, akromen) en die van 'kategese'. Elke proses het bestaan uit 'n drieledige voorbereiding van kategese of lering (vgl 1 Tim 4:13), asketisme (vgl 1 Kor 9:27), en liturgie as openbare diens (vgl Heb 8:6) (Scannell 1996:1). Hierdeur is die persoon in die geloofsgemeenskap ingelyf: 'they drilled into converts an exclusive identity as the people of God under a new Covenant' (Hinson 1996:77$78)$. Die rituele en gebruike was dus 'n stewige grondslag vir integrasie en eenheid (Meeks 2003:157), sodat die plaaslike geloofsgemeenskap van ander organisasies onderskeibaar was, en hulle 'korporatiewe' bewussyn en verbintenis kon uitleef (Hinson 1996:170).

In die huidige tydvak bestaan daar verskillende modelle en benaderings met betrekking tot die assimilasie van lidmate in gemeentes. Ford (2007:49) het in sy navorsing bevind dat ' $n$ groot aantal gemeentes oor geen proses beskik nie, omdat hulle verkeerdelik veronderstel dat assimilasie vanself sal plaasvind. Sommige beskik wél oor 'n assimilasieproses, maar dit bestaan bloot daaruit om die leierleraar persoonlik te ontmoet en sy of haar visie vir die geloofsgemeenskap te hoor. Vir ander is dit die geleentheid om persone by kleingroepe te betrek, sodat hulle kan voel hulle behoort. Daar is ook gemeentes wat op waardes fokus en voornemende lidmate oor die presiese geloofsoortuigings van die geloofsgemeenskap inlig (Dever \& Alexander 2005:61). Hierdie benaderings hou almal voordele vir die geloofsgemeenskap in, maar skiet nogtans tekort in die prosesmatige opneem van lidmate in die geloofsgemeenskap. Gevolglik is dit nodig om die belangrikste aspekte van suksesvolle en volledige assimilasie van nuwe lidmate te bepaal.

Burger (1991:20), Hendriks (1994:187), Lazenby (1995:22-23) en Van der Ven (1993:82) wys verskillende aspekte uit wat met die assimilasie van lidmate in die geloofsgemeenskap verband hou. Dit is egter Dingemans (1987:108-109) en Meeks (2003:84) wat die belangrikste aspekte, naamlik bedoelings (intensies), aktiwiteite (betrokkenheid) en kultuur aandui.

\section{Bedoelings}

Bedoelings of intensies verwys na mense se waardeoordele, vertroue en grondliggende ervaring ten opsigte van die geloofsgemeenskap. Mense beoordeel waardepatrone meestal onbewus. Wanneer hulle daarby aanklank vind, ervaar hulle 'n grondliggende gevoel dat die kerk 'n betroubare waarheid bemiddel. Hulle ontwikkel derhalwe die begeerte om aan te sluit, en maak dan dié begeerte (bedoeling) bekend (Basson 2006:88). Nie net die bedoelings van die nuwelinge nie, maar ook dié van die plaaslike geloofsgemeenskap behoort in die proses van assimilasie verklaar te word. Só word 'intensie' die dryfveer wat mense van voornemende en/of randlidmaatskap bring tot volle betrokkenheid by kerkaktiwiteite. Die kultuur speel ' $n$ ewe groot rol in hulle volledige assimilasie in die geloofsgemeenskap.

\section{Aktiwiteite}

Sinvolle aktiwiteite waarmee mense hulle kan vereenselwig, blyk ook waardevol te wees om mense te betrek. Volgens Lazenby (1995:22-23) is die kenmerke van lidmaatskap deelname aan die genadeverbond, geloof en betrokkenheid. Ook Hendriks (1994:187) wys geloof en betrokkenheid as kenmerke uit. Die kenmerke van geloof en betrokkenheid wat deur sowel Lazenby 
as Hendriks genoem word, is nou verwant. Geloof is die eerste aspek wat lei tot die intensie om lidmaat te word. 'Geloof' verwys hier na geloofskwessies én die aanvaarding van kultuur, met ander woorde hoe die geloof in die kulturele konteks gestalte kry. Betrokkenheid volg direk op geloof. Omdat mense glo, is hulle bereid om deel te neem. Een van die belangrike redes waarom mense voel dat hulle behoort, is waarskynlik omdat hulle betrokke is en dit hulle lewe sin gee. Deelname lei dus tot 'n gevoel van verbondenheid. Volgens Schaller (1986) kan dit soos volg verloop:

- 'n Persoon word deel van ' $n$ kleingroep in die geloofsgemeenskap, waar intieme verhoudings belangrik is, en sluit dan as lidmaat aan.

- 'n Persoon sluit aan as lidmaat, en raak dan betrokke by ' $n$ kleingroep, waar intieme verhoudings belangrik is.

- 'n Persoon sluit aan as lidmaat, en kry dan ' $n$ bepaalde amp in die geloofsgemeenskap.

- 'n Persoon sluit aan, en veroul ' $n$ bepaalde taak in die geloofsgemeenskap.

- Die persoon sluit aan, maar raak geensins betrokke nie.

(Schaller 1986:76-77)

Schaller het die studie onderneem met die oog op die retensie van lidmate. Met die eerste moontlikheid is behoud ná aansluiting die sterkste. Die tweede, derde en vierde moontlikhede toon ook goeie retensie van lidmate. Met die vyfde moontlikheid is die behoud van lidmate egter baie laag, want die persoon kan uiteindelik 'n blote toeskouer word, onaktief raak, en vir die geloofsgemeenskap verlore gaan. Schaller se bydrae toon aan hoe belangrik betrokkenheid in die assimilasieproses is. Wat egter onduidelik is, en nie met behulp van Schaller se model uitgeklaar word nie, is wat sou gebeur as die klein of belangegroep, of die lede daarvan, self nie volledig geïntegreer is nie. Hoe sal dit lidmaatbehoud beïnvloed? Wat sal gebeur as die groep ' $n$ negatiewe gesindheid teenoor die geloofsgemeenskap ontwikkel? Deelname aan 'n kleingroep wat lei tot verbondenheid met die groter geloofsgemeenskap, beteken nie noodwendig gelyke lojaliteite nie.

Volgens Schaller lewer die tweede moontlikheid ook goeie behoud van lidmate, maar laat dit 'n mens met dieselfde vrae as die eerste moontlikheid. By die derde moontlikheid waar die persoon ' $n$ amp in die geloofsgemeenskap beklee, is assimilasie volgens Schaller baie sterk. Die vraag is egter wat sou gebeur wanneer die persoon met ander lidmate bots, of selfs die amp verloor. Dit is ook nie duidelik hoe sulke persone teenoor die geloofsgemeenskap sal optree wanneer hulle die taak as minderwaardig ag, of nie by die kultuur van die plaaslike geloofsgemeenskap inpas nie.

Die hoofdoel van aktiwiteite is om mense te betrek by die gemeente. Een van die probleme waarmee leraars worstel, is lidmate se onbetrokkenheid en belangeloosheid (Basson 2006:207). Dié stand van sake lei daartoe dat lidmate uiteindelik weer vir die plaaslike geloofsgemeenskap verlore raak. Hoewel Schaller se navorsing heelwat vrae oproep, bly sy belangrikste bydrae die klem op betrokkenheid om mense aan die geloofsgemeenskap te verbind.

\section{Kultuur}

Die derde sy van assimilasie is die kultuur van die geloofsgemeenskap. Die gemeenskap van die gelowiges ontstaan weens die verwesenliking van die sendingopdrag (vgl Matt 22:36-40), en is die 'primary community by which the faith is expressed and perpetuated' (Hopewell 1988:14). Terwyl die kerk se verhouding met die Drie-enige God op 'n vertikale verbondenheid dui, verwys die gemeente as gemeenskap na dié wat glo en die verbondenheid horisontaal uitbrei (Möller 1994:288). Die horisontale uitbreiding van die verbintenis impliseer ' $n$ onderlinge verhouding (vgl 1 Joh 1:7) tussen mense in ' $n$ geloofsgemeenskap wat 'kinders van God' genoem word (Hunt 2002:84; Hopewell 1988:12-13). 'n Geloofsgemeenskap is uiteindelik meer as net ' $\mathrm{n}$ gewone vrywillige assosiasie wat deur 'n enkele gedeelde belang bymekaargehou word. Dit is 'n gemeenskap van mense wat weens wedergeboorte in verhouding met God gekom het, en nou as medebroer en -suster van die geloof in die plaaslike geloofsgemeenskap opgeneem behoort te word.

Terwyl geloofsgemeenskappe deur die inisiatief van God tot stand kom, bewerk deur die Heilige Gees en die verkondiging van die Woord, dra dit tog ook kenmerke van die eietydse konteks (Jinkins 1999:72, 73). Dit kan byvoorbeeld duidelik gesien word in die parallelle ontwikkeling van vroeë geloofsgemeenskappe en ander kultuurorganisasies, soos die Romeinse huishouding (Maier 2002:16), diasporasinagoges (Clarke 2000:166), vrywillige assosiasies soos die collegium funeraticium (begrafnisgenootskappe), die beskermheerstelsel (Clarke 2000:157) en filosofieskole (Meeks 2003:75-82). Die geloofsgemeenskap weerspieëldus die heersende kultuur, maar behoort steeds in sekere sleutelopsigte daarvan onderskeibaar te wees om getrou te wees aan die kerk se getuienistaak (Guder 1998:119). Die onderskeidende kenmerke laat 'n alternatiewe kultuur ontstaan wat deur gedrag, etiek, verhoudings en verdraagsaamheid gekenmerk word (Guder 1998:119-120).

Vanweë die eiesoortige eienskappe van 'n groep mense wat in Jesus se naam bymekaarkom, vorm daar met verloop van tyd 'n alternatiewe kultuur. Hulle samekoms word die sosiale manifestasie van die lewende Here en die krag van die Heilige Gees (Hendriks 2004:105; Guder 1998:153). Vir enige sosiale groep om te bly voortbestaan is 'n unieke kultuur belangrik (Meeks 2003:84). Sonder 'n bepaalde kultuur verbrokkel 'n plaaslike geloofsgemeenskap (Meeks 2003:84). Die kultuur skep grense waarbinne lidmate hulle veilig en tuis voel, en 'n omgewing waardeur mense beïnvloed en verander word (Guder 1998:153, 253).

Die begrip 'kultuur' is moeilik om te omskryf, en verwys hoofsaaklik na 'n komplekse geheel (Taylor 1998:88). Dit sluit ekonomiese, politieke en godsdienstige stelsels in (Omi 1990:40). Die konsep 'kultuur' verwys na die geloofsgemeenskap se lewenspatroon, en is ' $\mathrm{n}$ komplekse, geïntegreerde, dinamiese geheel(DeKlerk2001:62). Diekultuurvan diegeloofsgemeenskap het te doen met hoe hulle hulleself sien in interaksie met hulle konteks. Dit het te doen met die geloofsgemeenskap se 'habitual responses to the world' (Thinker 1993:113). Kultuur manifesteer in die geloof, gedrag, selfkonsep, liturgiese en teologiese tradisies, asook in die waardes van die geloofsgemeenskap. Vir die doeleindes van dié studie, behels kultuur drie belangrike dimensies: wêreldbeskouing, waardes en gedrag (vgl Malphurs 2007:99-101).

\section{Wêreldbeskouing}

Sonder dat hulle daarvan bewus is, stel kultuur mense in staat om ervaring te vertolk, om hulle lewens volgens ' $n$ bepaalde wêreldbeskouing te orden, en gedrag te beoordeel.

Die term 'wêreldbeskouing' is afgelei van die Duitse woord Weltanschauung. (Welt is die woord vir wêreld, en Anschauung beteken 'uitkyk' of 'beskouing'). As sodanig het die term sy oorsprong in die Duitse epistemologie en filosofie (MerriamWebster Online 2007). Weltanschauung verwys na die konseptuele skema of verwysingsraamwerk waardeur mense, hetsy bewus of onbewus, alles waaraan hulle glo, beoordeel; hoe hulle die realiteit en die wêreld vertolk (Nash 1992:16). Hierdie skema, of wêreldbeskouing, word 'n stel vooronderstellings oor die basiese samestelling van die wêreld. Die wêreldbeskouing is funksioneel omdat dit grondliggende vrae oor die betekenis van die lewe beantwoord. 'n Wêreldbeskouing behels vooronderstellings oor ten minste vyf belangrike sake, naamlik God, die werklikheid, kennis, moraliteit en die mensheid (Nash 1992:26).

Elke plaaslike geloofsgemeenskap het 'n heersende wêreldbeskouing. Die norm vir gemeentes is dat lidmate wat 
gereeld eredienste bywoon, dieselfde wêreldbeskouing sal hê, terwyl dit nie die geval sal wees met mense wat nie gereeld eredienste bywoon nie (Carroll, Dudley \& McKinney 1990:32). Mense wie se wêreldbeskouing van die gemiddelde benadering afwyk, is dikwels oorkrities teenoor die gemeente. Die lewens- en wêreldbeskouing blyk gewoonlik uit die taal van die gemeente (Basson 2006:60-61).

Volgens Malphurs (2007:99) bestaan mense se oortuigings op ' $n$ teoretiese en praktiese vlak. Teoretiese oortuigings is daardie aspekte van ' $\mathrm{n}$ wêreldbeskouing wat mense se lewens kan beïnvloed of nié - dit bly op ' $n$ teoretiese vlak. Mense se gedrag word gegrond op praktiese oortuigings wat dus hulle waardes en optrede beïnvloed.

\section{Waardes}

As ' $n$ geloofsgemeenskap het elke gemeente 'n stel unieke, gedeelde waardes. Malphurs (1996:34) beskryf sodanige gedeelde waardes in die plaaslike geloofsgemeenskap as '[t]he constant, passionate, biblical core beliefs that drive its ministry'. Gedeelde waardes kan in die volgende drie kategorieë vervat word:

- Kernwaardes omskryf die geloofsgemeenskap se karakter en kultuur (Malphurs 1996:31-47).

- Beskermde (verskanste) waardes verwys na die waardes wat in die reëls, regulasies en standaarde van die geloofsgemeenskap bestaan (Meeks 2003:84). Hierdie waardes skep duidelik omskrewe grense vir die geloofsgemeenskap (Gunton 2002:129)

- Belangewaardes verwys na die waardes wat weens die gedeelde belange en visie van die geloofsgemeenskap ontstaan (Basson 2006:58-59).

Lidmate beoordeel waardes meestal onbewus. Lidmate kan die geloofsgemeenskap se normatiewe waardes aanvaar, selfs al stem hulle persoonlike waardes nie met die gedeelde waardes ooreen nie. ' $n$ Lidmaat kan dus terselfdertyd oor 'n persoonlike sowel as 'n gemeenskaplike waardestelsel beskik. Waardes is die oortuigings wat gedrag bepaal. Hulle beïnvloed mense se leefwyse, die manier waarop hulle met ander omgaan, en hoe hulle die geloofsgemeenskap beoordeel. Indien ' $\mathrm{n}$ persoon in ' $n$ geloofsgemeenskap waardes openbaar wat in konflik is met die kernwaardes van die geloofsgemeenskap, lei dit tot stigmatisering.

Elke geloofsgemeenskap ontwikkel dus bewus of onbewus bepaalde waardes wat deel uitmaak van hul identiteit en kultuur, en wat ' $n$ invloed het op hoe daardie gemeenskap funksioneer. Volgens Shaw (2006) ontstaan hierdie waardes uit:

- basiese oortuigings oor reg of verkeerd wat nie noodwendig ' $n$ religieuse oorsprong het nie

- absolute óf relatiewe morele oortuigings

- intellektuele aannames oor ' $n$ benadering of gedrag wat die gewensde resultate sal oplewer

- ervaring van die konsekwensies van gedrag.

(Shaw 2006:50)

Hierdie waardes ontstaan onwetend óf doelbewus in die lewe van die plaaslike gemeenskap; dit bepaal die geloofsgemeenskap se karakter, reëls, gedeelde belange en visie. Mense binne én buite die geloofsgemeenskap is blootgestel aan hierdie waardes en dit het ' $n$ uitwerking op hulle interaksie met en beoordeling van die kerk (Anderson 1992:103). Om tuis te voel met die kernwaardes van ' $n$ geloofsgemeenskap, is voorwaarde vir ' $n$ individu om volledige te assimileer.

\section{Gedrag}

Kultuur het ook te doen met mense se gedrag. Dit sluit alle vorme van kommunikasie, aktiwiteite, tradisies en rituele in (Malphurs 2007:100). Gedrag vertoon op die oppervlak van die kultuur. Dit word veral in bepaalde tradisies vergestalt. 'n Geloofsgemeenskap se kultuur het ' $n$ bepaalde kulturele identiteit of persoonlikheid tot gevolg.
Die Bybel gebruik verskillende metafore om die geloofsgemeenskap se persoonlikheid en kultuur te beskryf. 'Huishouding van God' en 'liggaam van Christus' benoem die wese van die geloofsgemeenskap (Basson 2006:35; Hendriks 2004:105). Die persoonlikheid en kultuur van die gemeenskap verskaf ' $n$ bepaalde gemeente-identiteit, wat duidelik waargeneem kan word deur mense binne én buite die geloofsgemeenskap. Dié identiteit onderskei gemeentes van mekaar, sodat geen twee gemeentes dieselfde is nie (Ammerman 1998:78). Die identiteit kom voort uit sewe dimensies, naamlik die geskiedenis, tradisie, lewens- en wêreldbeskouing, simbole, rituele, demografie, en die unieke karakter en verhaal van die geloofsgemeenskap (Ammerman 1998:83-104; Carroll, Dudley \& McKinney 1990:23).

Dit is egter gevaarlik wanneer die gemeente-identiteit in ' $n$ subkultuur ontaard, en uiteindelik nie meer by God se Missio Dei weerspieël nie (Kimball 2003:95). Dan draai die rede vir die geloofsgemeenskap se bestaan om ander dinge, soos selfbehoud, instandhouding en die eie subkultuur (Woodberry, Van Engen \& Elliston 1996:121). Teologies beskou, het die geloofsgemeenskap geen ander identiteit as 'n missionale identiteit nie (Nel 2002:54).

In die identiteit van ' $n$ geloofsgemeenskap behoort twee belangrike sake duidelik onderskei te word, naamlik die wesenstaak van die geloofsgemeenskap, en die visie waardeur die geloofsgemeenskap op 'n unieke wyse en in 'n spesifieke konteks aan die wesenstaak gestalte gee (Basson 2006:58). Die gemeente se identiteit onderskei dit as 'n unieke geloofgemeenskap - anders as enige ander op ' $n$ bepaalde plek, in ' $n$ bepaalde situasie, en op ' $n$ bepaalde tyd in die geskiedenis (Nel 1994:22). Die geloofsgemeenskap se identiteit en kultuur behoort te bly ontwikkel en groei, sodat dit Jesus en sy koninkryk weerspieël en uitdra namate hulle al hoe meer mense bereik (Hendriks 2004:105).

' $n$ Goeie voorbeeld hiervan is die vroeg-Christelike gemeentes in $77-180 \mathrm{nC}$. Hulle het voor die uitdaging te staan gekom om ongelowige burgers van die Romeinse Ryk te bereik en te integreer, terwyl hulle ook hulle eie identiteit moes behou en as ' $\mathrm{n}$ missionale geloofsgemeenskap moes ontwikkel (Hinson 1996:77).

Wanneer die identiteit van die geloofsgemeenskap duidelik is, word assimilasie makliker omdat mense hulle daarmee kan vereenselwig en 'n ingeligte besluit kan neem om aan te sluit by die gemeente indien hulle ' $n$ gevoel van verbondenheid ervaar.

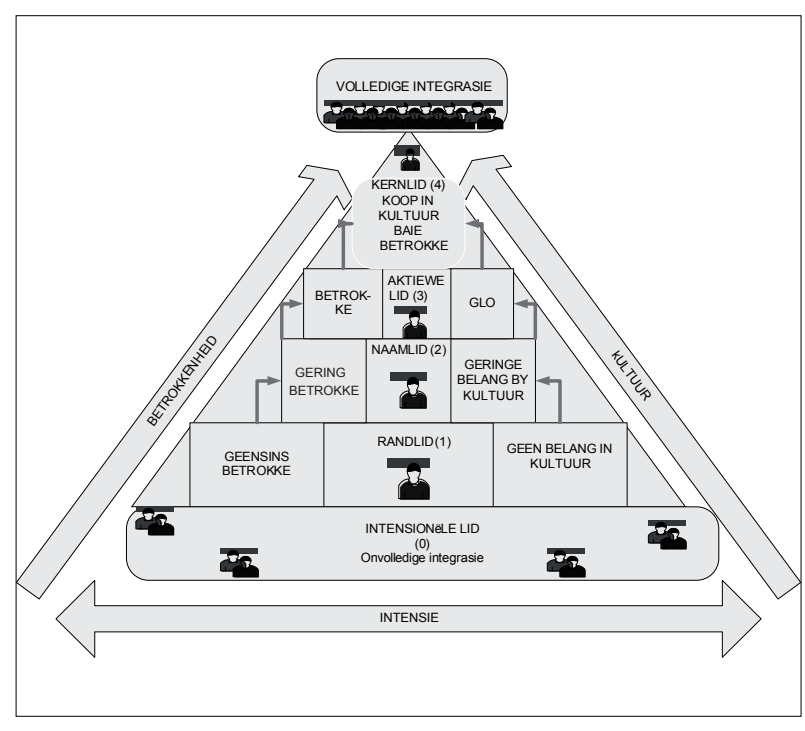

FIGUUR 1

Assimilasieproses van lidmate in gemeentes 


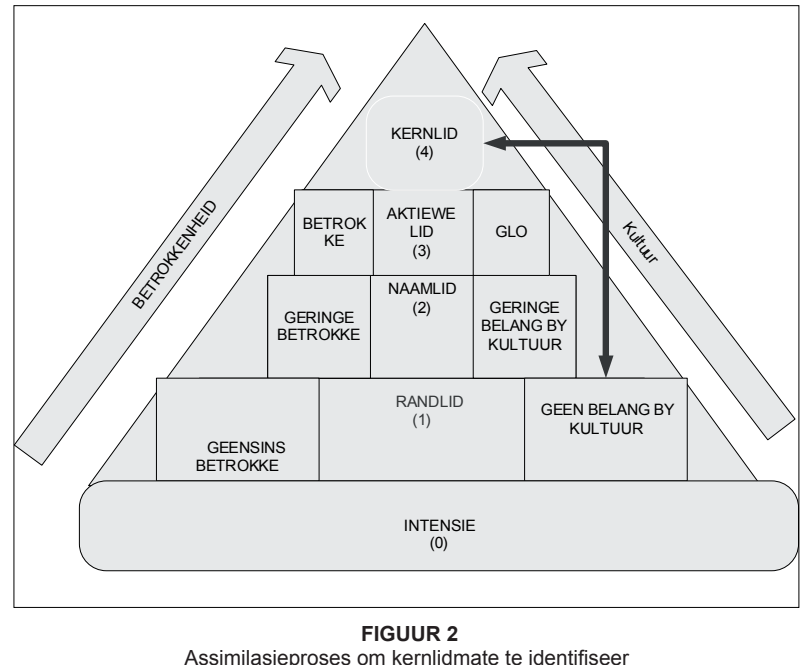

Assimilasieproses om kernlidmate te identifiseer

\section{`N NUWE MODEL VIR GEMEENTEASSIMILASIE}

Pinkstergemeentes loop die risiko van onvolledige assimilasie en integrasie. Vir volledige assimilasie en integrasie moet die drie belangrike komponente van die proses, naamlik bedoelings, aktiwiteite en kultuur, 'n gelyke rol speel.

Vervolgens word ' $\mathrm{n}$ skaal voorgestel wat kan bydra tot die assimilasieproses van lidmate in gemeentes. Die waarde van intensies, aktiwiteite en kultuur op verskillende vlakke kan hiervolgens beoordeel word.

Intensie (kyk figuur 1) is die eerste laag van assimilasie. Die koinonia-verhouding ontstaan, en verdiep namate persone by aktiwiteite betrek word en die kultuur van die geloofsgemeenskap volledig hulle eie maak.

Volgens die skaal vorm die drie belangrike vlakke van assimilasie, naamlik intensie, betrokkenheid by aktiwiteite en aanvaarding van die kultuur, ' $n$ driehoek. Die doel is dat voornemende lidmate deur middel van bepaalde prosesse van onder na bo deur die driehoek beweeg, sodat al drie komponente bymekaarkom. Gewoonlik word daar op simplistiese wyse net tussen lidmate en nie-lidmate onderskei. Aktiwiteite en kultuur is egter twee belangrike komponente in die assimilasieproses wat tot verskeie moontlike vlakke van verbondenheid kan lei.

Die vorige diagram dui vyf vlakke van verbondenheid met altesaam nege verskillende moontlikhede aan. Deur middel van hierdie skaal kan die vlak van assimilasie ten opsigte van betrokkenheid by aktiwiteite en die aanvaarding van die kultuur fyner bepaal word. Die persoon kan 'n voornemende lid, randlid, naamlid, aktiewe lid of kernlid wees. Die waardebalans van die komponente bepaal die mate van assimilasie. Indien iemand se aktiwiteitsbetrokkenheid byvoorbeeld op vlak 2 lê, behoort sy aanvaarding van die kultuur ook op vlak 2 te wees. Gemeentes worstel voortdurend in die praktyk hiermee. Ter opheldering word ' $n$ gevallestudie vervolgens voorgehou.

\section{Gevallestudie}

'n Lidmaat (Abrie) van gemeente $\mathrm{X}$ skakel by gemeente $\mathrm{Y}$ in. Abrie was baie betrokke by sy vorige gemeente, en spreek sy begeerte uit om by die nuwe gemeente betrokke te raak. Die pastor is verheug, want gemeente $Y$ het ' $n$ groot behoefte aan begaafde lidmate wat betrokke wil wees. Die pastor oortuig die bestuursraad om Abrie 'n leierspos te gee, aangesien sowel sy gawes as sy gesindheid dit regverdig. Abrie se betrokkenheid lê op vlak 4, en hy word onmiddellik as kernlidmaat opgeneem. Abrie onderskryf egter nog nie die waardes van die gemeente nie. Vir 'n ruk gaan dit goed. Abrie huldig die sterk oortuiging dat prediking hoofsaaklik oor mense se sondes moet handel. Abrie werk nog met ' $\mathrm{n}$ stel waardes uit gemeente $X$. Uiteindelik bots Abrie met die ander gemeenteleiers omdat hulle waardeoordele verskil. Ná verskeie gesprekke verlaat Abrie, sy gesin én ander lidmate wat met Abrie saamstem, die gemeente, en groot ongelukkigheid heers. Die pastor meen Abrie was ontrou; hy het van meet af aan bybedoelings gehad, met negatiewe gevolge. Wanneer die gevallestudie krities beskou word, lê een van die oorsake van die konflik duidelik daarin dat Abrie nie uit die staanspoor die waardes van die gemeente onderskryf het voordat hy as 'n kernlidmaat opgeneem is nie. Hierdie konflik en die gepaardgaande gevolge kon moontlik verhoed gewees het indien die gemeente oor ' $\mathrm{n}$ behoorlike assimilasieproses beskik het.

Dit beteken dat ' $\mathrm{n}$ persoon wat ten nouste betrokke is en die kultuur van die gemeente volledig aanvaar het, 'n kernlidmaat is wat die assimilasieproses betref (vgl figuur 2). Die persoon kan egter betrokke wees (vlak 3 ), maar geensins die waardes van die gemeente aanvaar nie (vlak 1), wat beteken dat die persoon se assimilasievlak in werklikheid die laagste van die twee komponente is. Die persoon is dus in wese bloot ' $n$ randlidmaat. Aan die ander kant kan die persoon die waardestelsel (kultuur) van die kerk volledig aanvaar (vlak 3 ), maar geensins betrokke wees nie (vlak 1 ). Weer eens is so ' $n$ persoon bloot ' $n$ randlidmaat vir die geloofsgemeenskap. Die vlak bepaal nie net die mate van assimilasie nie, maar ook die persoon se funksionele waarde vir die geloofsgemeenskap.

Die vraag is in watter stadium iemand as ' $\mathrm{n}$ lidmaat van die geloofsgemeenskap beskou word. In gemeentes met duidelike assimilasieprosesse sal lidmaatskap waarskynlik eers vanaf vlak 3 'n aanvang neem. In gemeentes sonder duidelike assimilasieprosesse kan dit van so laag as vlak 0 wees. Die uiteindelike doel van assimilasie is om elke persoon op vlak 4 te kry, waar hulle die gemeentewaardes (kultuur) volledig aanvaar én betrokke is by gemeenteaktiwiteite. Volledige assimilasie in die geloofsgemeenskap beteken dus sowel betrokkenheid as aanvaarding van die kultuur, waarop kernlidmaatskap volg.

\section{BEVINDING}

Die plaaslike gemeente is daarop afgestem om mense te beïnvloed, te verander en tot ' $n$ alternatiewe lewenstyl te begelei (Guder 1998:152). Dit is slegs moontlik indien mense doeltreffend bereik en in die geloofsgemeenskap opgeneem word. Lidmaatassimilasie geskied nie net ter wille van die uitbreiding van die kerk se lidmaatskap nie, maar om mense van verskillende vlakke van betrokkenheid by die lewe van die geloofsgemeenskap te integreer, sodat hulle die geloofsgemeenskap se kultuur volledig aanvaar en behoorlik by die gemeenskap se aktiwiteite betrokke raak, om sodoende in die persoonlikheid en die identiteit van die plaaslike geloofsgemeenskap opgeneem te word. Volgens Guder (1998:152) is dit 'a cultivating process that produces people in a particular way'.

Die assimilasie van nuwe lidmate is duidelik ' $n$ veeldimensionele proses. Dit behels drie belangrike komponente, naamlik die voornemende lidmaat se intensie, se kennis van en instemming met die plaaslike geloofsgemeenskap se kultuur (wat die wêreld- en lewensbeskouing, waardes en gedrag insluit), sowel as betrokkenheid by die geloofsgemeenskap se aktiwiteite. Die voorgestelde assimilasiemodel veronderstel dat die plaaslike geloofsgemeenskap nuwe lidmate prosesmatig van vlak tot vlak sal help ontwikkel tot kernlidmate word. 


\section{LITERATUURAANWYSINGS}

Ammerman, N.T., 1998, 'Culture and identity in the congregations [Kultuur en identiteit in die gemeentes]', in Ammerman, N.T., Carroll, J.W., Dudley, C.S. \& McKinney, W. (eds.), Studying congregations: A new handbook, pp. 78-104, Abingdon, Nashville, TN.

Anderson, L., 1992, A church for the 21 th century ['n Kerk vir die 21ste eeu], Bethany House, Minneapolis, MN.

Basson, E.F., 2006, 'Die AGS-gemeente as 'n missionale geloofsgemeenskap: 'n Deelnemende aksie navorsingsprojek', Fakulteit Teologie, DLitt et Phil-proefskrif, Universiteit van Johannesburg.

Bosch, D.J., 1979, Heil vir die wêreld, NG Kerkboekhandel, Pretoria.

Bruce, F.F., 1977, Paul [Paulus], Paternoster Press, Grand Rapids, MI.

Burger, C.W., 1991, Die dinamika van 'n Christelike geloofsgemeenskap, Lux Verbi, Kaapstad.

Carroll, J.W., Dudley, C.S. \& McKinney, W. (eds.), 1990, Handbook for congregational studies [Handboek vir gemeentelike studies], Abingdon, Nashville, TN.

Clarke, A.D., 2000, Serve the community of the church [Dien die gemeenskap van die kerk], Eerdmans, Grand Rapids, MI.

De Klerk, B.J., 2001, 'Wisselwerking tussen liturgie en kultuur in die Suid-Afrikaanse konteks: Enkele vertrekpunte', Praktiese Teologie in SA 16(2), 57-75.

Dever, M. \& Alexander, P., 2005, The deliberate church [Die doelbewuste kerk], Crossway, Wheaton, IL.

Dingemans, G.D.J., 1987, Een huis om in te wonen ... ['n Huis om in te woon], Boekencentrum, 's-Gravenhage.

Dobson, E.G., Leas, S.B. \& Shelley, M., 1992, Mastering conflict and controversy [Die bemeestering van konflik en omstredenheid], Multnomah Press, Portland, Oregon.

Dudley, C.S. (ed.), 1998, 'Process: Dynamics of congregational life [Proses: Die dinamika van gemeentelike lewe]', in Ammerman, N.T., Carroll, J.W., Dudley, C.S. \& McKinney, W. (eds.), Studying congregations: A new handbook, pp. 105-131, Abingdon, Nashville, TN.

Ferguson, E., Mchuah, M.P. \& Norris, F.W. (eds.), 1997, 'Catechumenate', in Encyclopedia of Early Christianity, Garland, New York.

Ford, K.G., 2007, Transforming church [Tranformeerende kerk], Tyndale, Salt River.

Frost, M. \& Hirsch, A., 2003, The shaping of the things to come: Innovation and mission for 21st-century church, Hendrickson, Peabody, MA.

Guder, D. L. (ed.), 1998, Missional church [Missonêre kerk], William B. Eerdmans, Grand Rapids, MI.

Gunton, C.E., 2002, The christian faith [Die Christelike geloof], Blackwell, London.

Hendriks, H.J., 1994, 'Missionêre gemeentebou', Praktiese Teologie in Suid-Afrika 9(2), 180-191.

Hendriks, H.J., 2004, Studying congregations in Africa [Bestudering van gemeentes in Afrika], Lux Verbi, Wellington.

Hinson, E.G., 1996, The Early Church: Origins to the dawn of the Middle Ages [Die vroeë kerk: Oorsprong tot aan die begin van die middeleeue], Abingdon, Nashville, TN.
Hopewell, J.F., 1988, Congregation stories and structures [Gemeenste stories en strukture], Fortress, Philadelphia, PA.

Hunt, S.J., 2002, Religion in the Western society [Geloof in die westerse samelewing], Palgrave, London.

Jinkins, M., 1999, The church faces death [Die kerk staar die einde in die gesig], Oxford, New York.

Kimball, D., 2003, The emerging church [Die ontluikende kerk], Zondervan, Grand Rapids, MI.

Lazenby, M.J., 1995, 'Kerklike lidmaatskap: Prakties-teologies verken', Praktiese Teologie in Suid-Afrika 10(1), 15-28.

Maier, H.O., 2002, The social setting of the ministry as reflected in the writings of Hermas, Clement and Ignatius [Die sosiale omgewing van die bediening soos weerspieël in die geskrifte van Hermas, Clement en Ignatius], Wilfrid Laurier University Press, Waterloo, Ontario.

Malphurs, A., 1996, Values driven leadership [Waardes gedrewe leierskap], Baker Books, Grand Rapids, MI.

Malphurs, A., 2007, A new kind of church: Understanding models of ministry for the 21st century ['n Nuwe soort kerk: Die verstaan van modelle vir die bediening van die 21ste eeu], Baker Books, Grand Rapids, MI.

Meeks, W.A., 2003, The first urban Christians [Die eerste stedelike Christene], Yale University Press, London.

Merriam-Webster Online, 2007, 'Weltanschauung [Ideologie]', in Merriam-Webster Online Dictionary, viewed 20 September 2007, http://www.m-w.com/cgi-bin/dictionary.

Möller, F.P., 1994, Woorde van lig en lewe reeks: ' $n$ Dogmatiese studie, deel 3, AGS Drukkers, Johannesburg.

Murray, S., 2001, Church planting [Kerk planting], Heraldpress, Scottdale, PA.

Nash, R.H., 1992, Worldview in conflict [Wêreldbeskouing in konflik], Zondervan, Grand Rapids, MI.

Nel, M., 1994, Gemeentebou, Orion, Halfweghuis.

Nel, M., 2002, 'Missionêre koers van 58 gemeentes in Suid Afrika: 'n Empiriese verslag', Praktiese Teologie in Suid-Afrika 17(1), 53-74.

Omi, D.N.P., 1990, Worship, culture and theology [Aanbidding, kultuur en teologie], Pastoral Press, Washington DC.

Scannell, T.B., 1996, sub verbo, The Catholic Encyclopedia [Die Katolieke Ensiklopedie], vol. III, viewed 20 September 2009, from http://www. newadvent.org/cathen/03430b.

Schaller, L.E., 1986, Assimilating new members [Assimilasie van nuwe lidmate], Abingdon, Nashville, TN

Schwarz, C., 1996, Natural church development [Natuurlike kerk ontwikkeling], Churchsmart Resources, Carol Stream, IL.

Shaw, P., 2006, The four V's of leadership, Capstone, Chichester.

Smit, G., 2003, 'Gawegedrewe bediening in missionerende gemeentes', Praktiese Teologie in Suid-Afrika 18(2), 158-178.

Taylor, M.C., 1998, Critical terms for religious studies [Kritieke terme vir godsdiens wetenskap], University of Chicago Press, Chicago, IL.

Thinker, G.E., 1993, Missionary conquest [Missionêre verowering], Augsburg Fortress, Minneapolis, MN.

Van der Ven, J.A., 1993, Ecclesiologie in context [Ecclesiologie in konteks], Kok, Kampen.

Woodberry, J.D., Van Engen, C. \& Elliston, E., 1996, Missional education for the twenty-first century [Missionale onderwys vir die twintigste eeu], Orbis Books, New York. 